\title{
EFFECTIVE USE OF BIO WASTE IN INSTITUTIONS
}

\author{
K.Karthick ${ }^{1}$, K.S.Prabhakaran ${ }^{2}$, K.Visagavel ${ }^{3}$ \\ ${ }^{1}$ PG Scholar, Knowledge Institute of Technology, Salem, Tamilnadu, India \\ ${ }^{2}$ Assistant Professor, Knowledge Institute of Technology, Salem, Tamilnadu, India \\ ${ }^{3}$ Professor, Knowledge Institute of Technology, Salem, Tamilnadu, India
}

\begin{abstract}
The study of the paper is based on generation of biogas from biomass source. The biogas have an alternative energy source .The accumulation and unhygienic handling of organic waste create several environmental and health problems including the emission of hazardous gases to the atmosphere and the organic waste water discharge from institutions is having the tendency to emit poisonous gases through anaerobic fermentation. Methane is the main gas generated by the anaerobic fermentation. The biomass has the property to produce the methane gas. This can be used for cooking, laboratory purposes. By implementing this technology, the bio waste can be effectively and efficiently managed for useful purposes, which are also economical and bio waste management.
\end{abstract}

Keywords: Biogas, Biomass, Waste utilization, Bio degradable waste. ***.

\section{INTRODUCTION}

The main aim is to produce the biogas from the bio waste of human and food waste in institution hostels. By utilizing waste in the proper way for reduce the economic impacts and to generate the biogas, further it will be used for the cooking and laboratory purposes. The renewable energy is essential factor in development since it stimulates and support economic growth and development. Anaerobic digestion is controlled by biological degradation process which allows the efficient capturing \& utilization of biogas (approx. 60\% methane and 40\% carbon dioxide) for energy generation. Anaerobic digestion of food waste is achievable but different types, they are composition of human waste, food waste and it results in varying degrees of methane yields, and thus the effects of mixing various types of human waste, food waste and their proportions should be determined on case by case basis.

Kitchen waste and human waste is organic material having the high calorific value and nutritive value to microbes, that's why efficiency of methane production can be increased by several orders of magnitude as said earlier. It means higher efficiency and size of reactor and cost of biogas production is reduced. Also in most of the institution and schools the kitchen waste and human waste is disposed in landfill method or discarded, which causes the public health hazards and diseases like malaria, cholera, typhoid. Inadequate management of wastes like uncontrolled dumping bears several adverse consequences: It not only leads to polluting surface and also groundwater through leachate and further promotes the breeding of flies, mosquitoes, rats and other disease bearing vectors. Also, it emits unpleasant odor \& methane which is a major greenhouse gas contributing to global warming.

Mankind can tackle this problem(threat) successfully with the help of methane, however till now we have not been benefited, because of ignorance of basic sciences like output of work is dependent on energy available for doing that work. This fact can be seen in current practices of using low calorific inputs human waste and food waste in institution to biogas plants, making methane generation highly inefficient. We can make this system extremely efficient by using kitchen waste/food wastes and human waste.

\subsection{Biogas}

Biogas is produced by bacteria through the bio-degradation of organic material under anaerobic conditions. Natural generation of biogas is an important part of bio-geochemical carbon cycle (Table-2). Biogas typically refers to a mixture of gases produced by the breakdown of organic matter in the absence of oxygen. Bio gas is produced by anaerobic digestion. biogas plant is nothing but a digester (Table-1).

Table-1 Anaerobic degradation of organic matter [4]

\begin{tabular}{|l|l|}
\hline Component & Concentration (by volume) \\
\hline Methane $(\mathrm{CH} 4)$ & $55-60 \%$ \\
\hline Carbon dioxide $(\mathrm{CO} 2)$ & $35-40 \%$ \\
\hline Water $(\mathrm{H} 2 \mathrm{O})$ & $2-7 \%$ \\
\hline Hydrogen sulphide $(\mathrm{H} 2 \mathrm{~S})$ & $20-20,000 \mathrm{ppm}(2 \%)$ \\
\hline Ammonia $(\mathrm{NH} 3)$ & $0-0.05 \%$ \\
\hline Nitrogen $(\mathrm{N})$ & $0-2 \%$ \\
\hline Oxygen $(\mathrm{O} 2)$ & $0-2 \%$ \\
\hline
\end{tabular}


Table-2 Composition of biogas.[5]

\begin{tabular}{|l|l|l|l|}
\hline Level & Substance & Molecule & $\begin{array}{l}\text { Bacter } \\
\text { ia }\end{array}$ \\
\hline Initial & Manure, vegetable & $\begin{array}{l}\text { Cellulose, } \\
\text { Proteins }\end{array}$ & $\begin{array}{l}\text { Cellul } \\
\text { olytic }\end{array}$ \\
\hline $\begin{array}{l}\text { Interme } \\
\text { diate }\end{array}$ & $\begin{array}{l}\text { Acid, gases, } \\
\text { oxidized, inorganic }\end{array}$ & $\begin{array}{l}\mathrm{CH} \text { COOH, } \\
\mathrm{CHOOH,} \\
\text { SO4, CO2 }\end{array}$ & $\begin{array}{l}\text { Acido } \\
\text { genic } \\
\text { hydro } \\
\text { genic }\end{array}$ \\
\hline Final & Biogas, reduced & $\begin{array}{l}\mathrm{CH} 4, \mathrm{CO} 2, \mathrm{H} 2 \\
\mathrm{~S}, \mathrm{NH} 3\end{array}$ & $\begin{array}{l}\text { Metha } \\
\text { ne } \\
\text { forme } \\
\text { r }\end{array}$ \\
\hline
\end{tabular}

\subsubsection{Characteristics of Biogas}

Composition of biogas depends upon feed material also. Biogas is about 20\% lighter than air has an ignition temperature in range of 650 to 750 0C.An odorless \& colourless gas that burns with blue flame similar to LPG gas. Its caloric value is 20 Mega Joules (MJ) /m3 and it usually burns with $60 \%$ efficiency in a conventional biogas stove.

Biogas digester systems provides a residue organic waste, after its anaerobic digestion that has superior nutrient qualities over normal organic fertilizer, as it is in the form of ammonia and can be used as manure for agriculture. Anaerobic biogas digesters also function as waste disposal systems, particularly for human wastes, and can, therefore, prevent potential sources of environmental contamination and the spread of pathogens and disease causing bacteria. Biogas technology is particularly valuable in agricultural residual treatment of human excreta and kitchen refuse (residuals).

\section{LITERATURE REVIEW}

The need for alternative sources of energy from renewable feedstock including biomass is on the increase. Biological methane production from renewable substrates (biomass) is one method that has proven promising. Biomass is a flexible feedstock that can be converted to solid, liquid and gaseous fuels by chemical and biological processes [1]. Biological conversion of biomass to methane $(\mathrm{CH} 4)$ by anaerobic digestion processes from both hand and mechanically sorted municipal solid waste, various types of fruit and vegetable solid waste, leaves, grasses, woods, weeds and marine/freshwater biomass has been reported [2].

\section{PROCESS}

\subsection{Waste Collection}

It includes the procedure and method of waste collection.it is done by two methods

\subsubsection{Direct Collection}

The sanitation waste is directly collected through pipelines of suitable dimension. It is better to have a poly vinyl chloride (PVC) for waste collection, which is of corrosion resistant in nature and having a comparatively better life the liquid kitchen waste is also being collected directly by the aid of PVC pipes.

\subsubsection{Indirect Collection}

The solid kitchen waste is being collected and is introduced into the digester. The waste is being collected by the help of waste collection drum which are being placed at different places where the bio mass is being generated.

\subsection{Segregation}

The waste which are being collected by indirect method are being segregated into biodegradable and non- biodegradable wastes. The biodegradable waste will be introduced into the digester.

\subsection{Digestion}

Anaerobic digestion is used for decomposing the biodegradable material and thereby producing biogas which can be used as source of fuel in kitchen.in anaerobic digester the bio degradable material will be broken down by the help of microorganism in the absence of oxygen.

\subsection{Gas Extraction}

The gas which has been extracted from the digester will be collected in a collection tank which will be further used as source of fuel for kitchen and laboratory use the construction of the gas collector is done by considering the safety issues.

\section{RESULTS AND DISCUSSION}

From the following studies it's clear that in some institution. The bio waste is not utilized efficiently. Due to improper usage of bio waste from the institution, it tend to create environmental health effect like cholera, malaria, typhoid, etc. By this improper usage the impact of this problem is high and it should consider as a major problem in society. As well as preventing from the previous following effect it can be useful for the many other application purposes if it is utilizing in proper way.

And also due to improper utilization of bio waste producing of carbon dioxide is high. Now a days the producing $\mathrm{CO} 2$ in high from various process and this $\mathrm{CO} 2$ has a tendency to reduce the oxygen level in this atmosphere.

Waste Treatment Capacity _ $\quad 74 \mathrm{Kg}$ bio waste \& 2000-2200 Litre of organic Waste Water

Volume of Digester

- 32000 Litre

Suitable for

- 55-60 members in

hostel

Space required for the installation - $40 \mathrm{Sq}$ Meters 
Gas generation per day

Liquid fertilizer generation

32 Cum Biogas

Per month economic reduction
- $\quad 32$ Cum Biogas

- 640Litres per day

- 16 Kg. LPG

Rs.43300 /-

Human waste produced per day is around 900-1600g in this process 55-60 members were chosen. The waste treatment capacity is $74 \mathrm{~kg}$ bio waste and $2000-2200$ litre of organic waste water. The result obtained from this process is that $16 \mathrm{~kg}$ of LPG is generated by using the bio waste .By implementing this process in institution the cost incurred in purchasing of commercial cylinders can be reduced and the renewable source can be used effectively and efficiently .

In major institutions the utilization of canteen, laboratory, mess, are high .For operating this aspects there is requirement of heat source. For this institution are purchasing the cylinders for producing heat source. The properties are Change in volume as a function of temperature and pressure. Change in Calorific value as function of temperature, pressure and water vapor as a function of temperature and pressure. And also the cost of commercial gas is high compared to the domestic purpose .The benefits of this technology is Production of energy through transformation of the organic waste to very high quality fertilizer. Environmental advantages through protection of soil, water, land.

\section{CONCLUSIONS}

The result of this process is the production of biogas from human waste, kitchen waste has shown that biogas can be produced from these wastes by anaerobic digestion .These waste are readily available in the institution and it can be a source of fuel if used properly. Through this carbon dioxide emission can be reduced effectively. The use of biogas for cooking and laboratory use for heating helps to reduce the cost.

\section{REFERENCES}

[1] Ramachandra, T.V., Joshi, N.V., and Subramanian, D.K., (2000), Present and prospective role of bioenergy in regional energy system. Renewable and sustainable energy review, 4, p 375.

[2] Gunaseelan, V.N., (1997), Anaerobic digestion of biomass for methane production: A review, Biomass and bioenergy, 13(1), pp 83-114.

[3] Radha, A., Visvanathan C., Armaki, T. and AnnachHatre P., (2006), Sequential batch and continuous anaerobic digestion of municipal solid waste in pilot scale digesters.

[4] Omer, A.M., et al. Biogas energy technology in Sudan.Renewable Energy, 28 (3): 499-507, 2003.

[5] Suyog Vij, Biogas production from kitchen waste, national institute of technology, rourkela 